\title{
ІНДИВІДУАЛЬНІ ОСОБЛИВОСТІ СТАНОВЛЕННЯ ПРОФЕСІЙНОЇ КОМПЕТЕНТНОСТІ МАЙБУТНІХ МЕДИЧНИХ СЕСТЕР
}

\author{
Л. В. Задирака \\ Ватутінська філія Черкаського медичного коледжу \\ ДВНЗ «Тернопільський державний медичний університет \\ імені І. Я. Горбачевського МОЗ України»
}

У статті здійснено теоретичний аналіз впливу індивідуальних особливостей майбутніх медичних сестер на професійне становлення та розвиток професійно важливих характеристик особистості для самореалізації в майбутній професії.

\section{INDIVIDUAL FEATURES OF FORMATION THE PROFESSIONAL COMPETENCE OF FUTURE NURSES}

\author{
L. V. Zadyraka \\ The filial of Cherkasy Medical College in Vatutine, \\ I. Horbachevsky Ternopil State Medical University
}

The article dwells on theoretical analysis of the impact of the individual characteristics of future nurses for professional formation and development of professional and important characteristics for individual selfrealization in future profession.

Вступ. Характер докорінних змін, що відбуваються в Україні, суперечності та проблеми нинішнього складного періоду, які переживає суспільство, впливають на процес професійного становлення медичних працівників, оскільки своєрідне поєднання труднощів, спричинених, з одного боку, їхньою об'єктивною складністю й динамічністю, а з іншого, соціальноекономічними негараздами створює у багатьох випадках особливо напружені соціально-психологічні ситуації професійної діяльності.

Сучасний рівень розвитку медичної науки й охорони здоров'я поряд з іншими аспектами визначається також і зміною вимог Галузевого стандарту вищої освіти до кваліфікаційної характеристики медичної сестри. Сфера професійної компетентності середніх медичних спеціалістів поступово розширюється і включає все більше маніпуляцій, які раніше виконувалися лікарем. Медична освіта в Україні вимагає реформування по суті наближення до реальних потреб практичної охорони здоров'я [1].

Різним аспектам формування професійної компетентності фахівців присвячені праці вітчизняних і (сЛ. В. Задирака, 2016 зарубіжних авторів: І. Г. Агапова, К. А. АбульхановоїСлавської, Б. С. Гершунського, Н. В. Кучерявої, І. Н. Кулікової, А. В. Хуторського, С. Е. Шішова, Д. Баррета, Д. Равена та ін.

У працях учених підкреслюється важливість проблеми формування професійної компетентності медичних сестер та пропонується звернути увагу на систему підготовки спеціалістів сестринської справи з урахуванням перспектив розвитку потреб охорони здоров'я (К. А. Аяпов, І. В. Бубликова, З. В. Гапонова, Г. М. Перфільєва, Ф. Е. Вартанян, О. А. Орлов, Н. І. Гаврилов, В. П. Фофанов, С. А. Мухіна, І. І. Тарновська та ін.).

На сучасному етапі дослідження встановлено, що досі зусилля вчених були спрямовані на вдосконалення рівня підготовки майбутніх медсестер (М. В. Блохіна, Л. І. Вассерман, А. В. Дружинін, В. Є. Коган, Н. А. Сербіновська), розв'язання питання збереження здоров'я самих медичних працівників (І. М. Кайдалова, В. В. Косарєв), професійного становлення медичних працівників середньої ланки (Л. Б. Виноградов, В. В. Ярцев та ін.). Однак питання становлення професійної компетентності майбутніх медичних сестер залишається малодослідженою проблемою, незважаючи на очевидну 
актуальність як із соціального, так і з наукового погляду [5].

Розглядаючи проблеми формування професійної компетентності майбутніх медичних сестер необхідно відзначити, що сьогодні у сфері освіти найбільш яскраво проявляється позиція суб'єктивної значущості людини, суть якої полягає в розкритті індивідуального внутрішнього потенціалу, резервів розвитку, особистісного досвіду.

Вибір теми дослідження зумовлений потребою удосконалення системи підготовки середнього медичного персоналу та недостатнім вивченням проблеми становлення професійної ідентичності майбутніх медсестер, зокрема необхідністю розроблення психолого-педагогічних засад управління процесом професійного становлення майбутніх медсестер 3 метою підвищення ефективності їх фахової підготовки шляхом урахування та розвитку індивідуальних психолого-педагогічних характеристик.

Основна частина. Професійна підготовка фахівців майбутніх медсестер - це динамічне складне педагогічне явище, яке здійснюється на основі цілеспрямованого, організованого, науково обґрунтованого формування особистості майбутнього медика. Підвищення якості підготовки молодих медичних спеціалістів вимагає глибокого осмислення змісту майбутньої професійної діяльності з метою забезпечення актуальності та повноти знань, умінь і навичок майбутніх медиків. Необхідно також досягти усвідомлення взаємозв'язків між соціальними процесами та відповідними явищами в медичній галузі. Мету навчання студенти повинні сприймати так, щоб у них пробудився інтерес до пізнання, навчальної та майбутньої професійної діяльності, виникло бажання проявити вольові й інтелектуальні зусилля для досягнення навчальних цілей.

Для вибору професії медичної сестри особливе значення мають специфічні здібності і «вроджені задатки» (за А. Н. Леонтьєвим), які являють собою особливості будови мозку, нервової системи і виступають як природні передумови розвитку здібностей. У кожної особистості зазвичай закладені елементи здібності і нездатності до того чи іншого роду діяльності [3].

Відомо, що успішна підготовка майбутніх медичних сестер до професійної діяльності висуває підвищені вимоги до їх психофізіологічних можливостей, особистісних якостей. Адже студенти - особлива соціальна група, найбільш підвладна впливу таких факторів, як нервово-емоційне напруження і соціальна незахищеність.

Важливу роль у діяльності майбутньої медичної сестри відіграють особливості інтелектуальної сфери: висока стійкість та обсяг уваги, хороша довготривала, оперативна і зорова пам'ять, відмінна спостережливість, оперативне мислення, швидке прийняття рішень, високий самоконтроль. Емоційно-вольові якості особистості медичної сестри вимагають самовладання в напружених ситуаціях, врівноваженості, зібраності, рішучості, впевненості в собі і т. п. Професія медсестри передбачає також високий рівень розвитку зорових, слухових і тактильних відчуттів. Останні мають велике значення при визначенні температури тіла, знаходженні вени. На базі цих відчуттів формується спостережливість. Різнопланова діяльність медсестри вимагає активного мислення при вирішенні різних завдань. Часто вона змушена діяти в екстремальних умовах, коли необхідно швидко прийняти оптимальне для певної ситуації рішення. Тут необхідні кмітливість, спритність, самовладання. Одним з важливих професійних задатків повинна бути здатність до емпатії.

Багато особистісних якостей майбутньої медичної сестри формуються у період професійної підготовки. Дуже важливим фактором виступає допомога студенту в розвитку своїх здібностей у даній професії, в роз'ясненні психологічних факторів негативних переживань і методів їх подолання. I головне - допомогти з'ясувати наявність необхідних задатків і здібностей для роботи в ролі медичної сестри $[7,8]$.

Комплексний підхід до формування професійної компетентності майбутніх медичних фахівців визначається не тільки тим обсягом знань, який отримує студент у процесі навчання. Ступінь засвоєння знань істотно залежить також і від індивідуальних особливостей студента. З'ясувалося, що важливу роль у цьому процесі відіграють не тільки характеристики пізнавальних процесів (сприйняття, уваги, пам'яті, мислення й ін.), але й індивідуально-типологічні особливості особистості і їі мотивація.

Застосування різноспрямованих методів навчання при викладанні дисциплін у майбутніх медсестер сприяє ранній професіоналізації навчання, створює базу для розвитку мислення, забезпечує міждисциплінарну інтеграцію дисциплін, і як результат, сприяє розвитку професійно важливих якостей медичного спеціаліста та готовності до майбутньої професійної діяльності. 
Для майбутніх медичних спеціалістів виокремлено п'ять основних категорій професійно важливих якостей: професійно-творчі, морально-духовні, психофізіологічні, соціально значущі, емоційно-вольові якості [2].

Ефективність застосування різноспрямованих методів проблемного навчання суттєво залежить від педагогічних умов, в яких відбувається їх впровадження. Саме педагогічні умови забезпечують регуляцію особистісних, психологічних, мотиваційних, комунікативних факторів навчання.

До педагогічних умов, що обов'язково мають бути створені при застосуванні навчання медсестер, зараховано: професійну спрямованість навчальних проблем; належний рівень методичного забезпечення; використання в навчальному процесі комп'ютерної техніки, мультимедійних систем, мережі «Інтернет». Сприятлива умова - систематичний моніторинг навчальних досягнень і рівня професійної готовності студентів. До важливих умов також належать: поступове впровадження різноманітних методів навчання; високий професійний рівень викладачів, відсутність у них антиінноваційного бар'єра.

Особливу увагу необхідно зосередити на таких умовах, як ефективна взаємодія викладача і студентів під час застосування методів, психологічна готовність студентів до такої роботи та психологічний комфорт студентів під час навчання [7]. Почуття комфорту, позитивний емоційний стан, позитивний психологічний клімат у медичному навчальному закладі $\epsilon$ сприятливими факторами в навчальному процесі. Але саме при впровадженні таких методів навчання, як евристична бесіда, дискусія, навчальний диспут, «мозковий штурм», ділова гра, робота в малих групах, в яких особливо тісно пов'язані інтелект і емоційновольова сфера особистості студента, вони набувають особливого значення [3].

Професіоналізм діяльності характеризується гармонійним поєднанням високої професійної компетентності та професійних умінь і навичок на рівні професійної майстерності. У ході засвоєння професійної діяльності в міру переходу на більш високі рівні професіоналізму настає етап стабільного використання накопичениху професійному досвіді способів і засобів виконання завдань на рівні високих зразків, що стає основою розвитку професійної майстерності, для досягнення якого необхідно володіти певним особистісним потенціалом. Це - загальні та спеціальні здібності, базові знання, мотивація досягнень, спрямованість на саморозвиток, адекватна самооцінка та професійна компетентність. Професійна компетентність у більшості випадків визначається як поєднання психічних якостей, як психічний стан, що дозволяє діяти самостійно і відповідально, як володіння людиною здатністю і умінням виконувати певні професійні функції. На думку Ю. Г. Кузнєцова, професійна компетентність являє собою властивість особистості, що дозволяє ефективно взаємодіяти з професійним середовищем завдяки наявності необхідного фонду переживань, знань, відносин (атрибутів свідомості); виступає провідним регулятором професійного розвитку особистості; передбачає глибоке розуміння професійного середовища і свого місця в ньому [1].

Основоположним чинником професійної медичної освіти стає розвиток особистісної сфери, а метою формування професійної компетентності. Успішному становленню професійної компетентності майбутніх медсестер у процесі навчання сприяє усвідомлення і, головне, розвиток основних якостей особистості, котрими повинен володіти кожен медичний працівник середньої ланки, при цьому величезне значення в його практичній діяльності має орієнтація на іншу людину як рівноправного учасника діяльнісного процесу. Таким чином, для формування професійної компетентності майбутнього медичного працівника середньої ланки необхідні: володіння принципами взаємного співробітництва, поєднання професійних якостей та особистісних позицій, прагнення до саморозвитку і самореалізації у своїй майбутній професійній діяльності.

Узагальнюючи вищезазначене, можна сказати, що компетентність - це особистісний досвід у вигляді комплексу знань, умінь, навичок, цінностей, способів сприйняття, мислення, дій, переживань, цілей, а також способів і критеріїв оцінки, що переросли в модель дій при будь-якій ситуації і в будь-яких умовах. При цьому сама компетентність розглядається як високий рівень розвитку професійної діяльності, транслятором виступає освіта, а носіями компетентності є як окремо взята особистість, так і суспільство загалом.

Висновок. Для формування професійної компетентності майбутнього медичного працівника необхідні: володіння принципами взаємної співпраці, поєднання професійних якостей і особистісних позицій, прагнення до саморозвитку та самореалізації у своїй майбутній професійній діяльності. Основоположним у професійній медичній освіті стає розвиток особистісної сфери та основ формування професійної компетентності. 
Застосування різноспрямованих методів навчання при викладанні дисциплін у майбутніх медсестер сприяє розвитку професійно важливих якостей

\section{ЛІТЕРАТУРА}

1. Якість підготовки медичних сестер - нагальна вимога часу / М. В. Банчук, О. П. Волосовець, І. І. Фещенко, [та ін.] // Буковинський медичний вісник. - 2007. - С. 7.

2. Васильева Л. А. Особенности формирования профессиональной компетентности будущих медицинских работников среднего звена / Л. А. Васильева // Вестник ОГУ. - 2011. - № 4. - С. 19-22.

3. Перепелица А. В. Важность врожденных способностей в профессиональном самоопределении будущих медицинских сестер [Электронный ресурс]. / А. В. Перепелица. - Режим доступу: http://sociosphera.com/ publication/conference/2013/182/vazhnost_vrozhdnnyh_ sposobnostej_v_professionalnom_samoopredelenii_ buduwih_medicinskih_sestr/ медичного спеціаліста та готовності до майбутньої професійної діяльності.

4. Медична освіта у світі та в Україні / Ю. В. Поляченко [та ін.]. - К. : Книга плюс, 2005. - 383 с.

5. Попіль М.І.Психологічні особливості становлення професійної ідентичності майбутніх медсестер: дис. ... канд. психол. наук : 19.00.07 / Попіль М. І. - Дрогобич, 2009. - 196 c.

6. Радзієвська І. В. Формування професійної компетентності медичних сестер / І. В. Радзієвська // Проблеми освіти. - 2008. - № 57. - С. 69-73.

7. Селлман Д. Как стать медсестрой / Д. Селлман, П. Снеллинг ; пер. с англ. - К. : ВСВ «Медицина», 2012. $176 \mathrm{c.}$

8. Стрижак Л. Н. Психология и педагогика : учеб. пособие / Л. Н. Стрижак. - М. : МГИУ, 2006. - 335 с.

Отримано 10.02.16 